\title{
"Engaging perceived value towards political marketing mix for head of region voting decision"
}

\author{
Asep Ferry Bastian \\ AUTHORS Margono Setiawan \\ Armanu \\ Fatchur Rohman (D https://orcid.org/0000-0001-7265-3324
}

Asep Ferry Bastian, Margono Setiawan, Armanu and Fatchur Rohman (2019).

ARTICLE INFO Engaging perceived value towards political marketing mix for head of region voting decision. Innovative Marketing , 15(4), 14-26.

doi:10.21511/im.15(4).2019.02

DOI

http://dx.doi.org/10.21511/im.15(4).2019.02

RELEASED ON

Friday, 15 November 2019

RECEIVED ON

Saturday, 27 July 2019

ACCEPTED ON

Friday, 25 October 2019

\section{(cc) EY}

LICENSE

This work is licensed under a Creative Commons Attribution 4.0 International License

JOURNAL "Innovative Marketing "

ISSN PRINT

$1814-2427$

ISSN ONLINE

$1816-6326$

PUBLISHER

LLC "Consulting Publishing Company "Business Perspectives"

FOUNDER

LLC "Consulting Publishing Company "Business Perspectives"

NUMBER OF REFERENCES

43
NUMBER OF FIGURES

2
NUMBER OF TABLES

4

(C) The author(s) 2022. This publication is an open access article. 


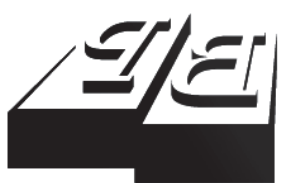

BUSINESS PERSPECTIVES

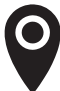

LLC "CPC "Business Perspectives" Hryhorii Skovoroda lane, 10, Sumy, 40022, Ukraine

www.businessperspectives.org

Received on: $27^{\text {th }}$ of July, 2019 Accepted on: $25^{\text {th }}$ of October, 2019

(C) Asep Ferry Bastian,

Margono Setiawan, Armanu, Fatchur Rohman, 2019

Asep Ferry Bastian, Ph.D. in Management Science, Doctorate student of the Department of Management Science, Faculty of Economics and Business, Brawijaya University, Indonesia.

Margono Setiawan, Ph.D. in Economics Science, Professor of the Department of Management Science, Faculty of Economics and Business, Brawijaya University, Indonesia.

Armanu, Ph.D. in Management Science, Professor of the Department of Management Science, Faculty of Economics and Business, Brawijaya University, Indonesia.

Fatchur Rohman, Ph.D. in Management Science, Lecturer of the Department of Management Science, Faculty of Economics and Business, Brawijaya University, Indonesia.

\section{(ㄷ) (i)}

This is an Open Access article, distributed under the terms of the Creative Commons Attribution 4.0 International license, which permits unrestricted re-use, distribution, and reproduction in any medium, provided the original work is properly cited.
Asep Ferry Bastian (Indonesia), Margono Setiawan (Indonesia),

Armanu (Indonesia), Fatchur Rohman (Indonesia)

\section{ENGAGING PERCEIVED VALUE TOWARDS POLITICAL MARKETING MIX FOR HEAD OF REGION VOTING DECISION}

\begin{abstract}
This study aims to determine and analyze the role of perceived value in influencing political marketing mix on voting decision for Head of Region in the Election of Governor and Deputy Governor of Banten in 2017. The population of this study involves people who have the rights to vote in Banten and are kept on the permanent voter list. Sample of this study consists of 664 respondents, in which most of the respondents include casual workers, outsourcing, casual daily laborers, housewives, and workers who do not need special skills. The proportional random sampling technique was utilized in determining the number of respondents. SEM (Structural Equation Modeling) was conducted by applying WarpPLS 6.0. The results of the study indicated that there is a positive and significant relationship between political marketing mix and perceived value concerning the voting decision, as demonstrated by positive and significant effect on perceived value. The findings confirmed that political marketing mix influenced the decision to elect a Head of Region mediated by perceived value. To improve the decision to vote, the researchers believe/suggest that providing attention to political products such as branding of political candidates, is thus deemed necessary.
\end{abstract}

Keywords politics, marketing, decision, perceived value

JEL Classification M31

\section{INTRODUCTION}

Concerned political actors, specifically in Indonesia, inarguably require a thorough study related to political marketing and the trends conveying the voter behavior, due to several reasons such as: (1) Indonesia multiparty system, ever existing in 1955, which was reimplemented; (2) Indonesia two election natures which include Pileg (to elect people's representatives) and Presidential Election (to elect president and vice president); and (3) the existence of Government Regulation Number 6/2005 concerning Election, Ratification, Appointment and Dismissal of Regional Heads and Deputy Regional Heads (Firmanzah, 2007).

The political competition map has been inevitably wide-open, where political candidates are not only allowed to participate in election directly through the supporting political parties but also as an independent candidate. This phenomenon was stipulated in the decision of the Constitutional Court (MK) on July 23, 2007.

In line with the development of the political system in Indonesia, the study of political marketing has grown rapidly, due to five essential factors. Firstly, the multiparty political system has provided the free- 
dom to establish political parties. Secondly, increasing competition among political parties is inevitable. Thirdly, voters have more freedom to make their choices, which further encourages the application of political marketing. Fourthly, political parties have more freedom to determine the platform and identity. Lastly, election serves as an important moment in the nation's journey, involving political elites to effortfully participate. The idea of making political marketing as a new discipline does indeed open into debate. However, from the aspect of needs, political marketing has been practiced for quite a long time. Historically, political marketing has long been growing and developing in the European countries. In the 1970s, the British Conservative Party advertised their party in the election through Saatchi advertising agency. As a result, they successfully delivered Margaret Thatcher to be the Prime Minister of England in 1979. The victory of the Irish woman President, Mary Robinson, was also inseparable from the political marketing strategy that was commonly applied in the business world. Meanwhile, in Germany, Green Party and PSD also employed a marketing strategy to defeat Helmut Kohl who had been governing for a long time (Nursal, 2004).

The concept of perception is definitely applicable in political marketing (Brennan, 2004) according to the theory of perceived value proposed by Parasuraman (1997). The perception of value in political marketing can also be influenced by political attributes as produced by political marketers. In making purchase decisions, consumers are strongly influenced by their perception of the products or services offered. Therefore, one of the key elements of the success of a marketing strategy involves the development of products stimulated by promotional programs related to the needs of customers (in accordance with consumer expectations) (Assael, 1995). A person's perception of stimuli can be formed through three stages, including: exposure, attention, and interpretation (Solomon, 2004). Value is also defined as an evaluation of the overall benefits of a product or service, which is based on consumer perceptions of what they have experienced, both in the form of products and services. Consumer value can also be interpreted as something perceived by consumers, without the influence of the sellers. Thus, consumer value is what is desired by consumers and an assessment of the use of products or services offered by sellers (Woodruff, 1997).

In making the rational decision, one collects as much information as possible about the desired product or service and combines with information that has been previously collected (Solomon, 2004). The phenomenon of monetary policy in Indonesia serves as a driving factor in voting decision. Based on a survey conducted by the Indonesian Political Indicators Survey in 2017, 24 percent of Tangerang City residents who are part of Banten Province accept monetary policy (perceived as normal treatement), while 76 percent indicate that they reject monetary policy.

Political mix marketing variable, which consists of political products, political promotion, political prices, political places, has a direct effect on voting decision with significant results (Alwi, 2011). Meanwhile, the research conducted by Widagdo et al. (2014) postulates different results where the relationship between political price and the voting decision was inconsistent and insignificant. Other political marketing mix, consisting of political products, political promotions, political places, has a significant effect.

The relationship between the perceived value and voting decision refers to the results of a research conducted by Chang and Wildt (1994) indicating the relationship between product attribute information, perceived value, encouragement, and purchase decisions (conventional marketing). Brennan (2004) stated that the concept of perception is applicable in political marketing. A study conducted by Parasuraman (1997) found out that perceived value in political marketing can be influenced by political attributes generated by political marketers.

This research was conducted to find out and analyze the role of perceived value in influencing political marketing mix on the decision to vote for a Head of Region in the Election of Governor and Deputy Governor of Banten in 2017. 


\section{LITERATURE REVIEW}

Political marketing is defined as the application of marketing principles in political campaigns that are diverse in individuals, organizations, procedures, and involve analysis, development, execution, as well as campaign management strategies by candidates, political parties, governments, lobbyists, and certain groups to direct public opinion towards their ideology (Newman \& Perloff, 2004). The relationship between marketing philosophy and its application in politics through PMC and political market orientation has been investigated by O'Cass (2001). Basically, the findings of this study indicate that the emphasis of marketing on voter needs and satisfaction which are important for political party functionaries. Besides, Eavani and Kamran (2012) described the concept of the political marketing mix from the perspective of the history of its development. One important part of this research lies on the criticism of the concept of political marketing mix as a controllable variable which provides a wide possibility for empirical testing. These findings are in accordance with a research conducted by Widagdo et al. (2014) pointing out that: (1) there is an effect of political products, including party platforms, track records, and personal characteristics, on the decision to vote a prospective candidate, (2) there is an effect of other parts of political products on the decision to vote certain political party, (3) there are political prices, which include political costs, psychological costs and images, excluding the decision to vote candidates and political parties.

Perception is a process carried out by individuals to choose, organize and interpret stimuli into images about the world that are meaningful and reasonable (Schiffman \& Kanuk, 2007). Sensation is an immediate and direct response from the five senses to simple stimuli (advertising, packaging, brandsing). Zeithaml (1988) defines consumer perceived value (PNK) as a consumer's overall assessment towards the use of products/services based on benefits and sacrifices made. In other words, PNK is a consumer's entire assessment of the use of a product/service, which is based on perceptions of what is received and what is given. Due to its variety among consumers, PNK reflects barter between the use and components of a product which is useful for the users. The influence of internal factors or personal factors (perception, family, motivation and involvement, knowledge, attitudes, learning, age groups, and lifestyle) provides such important and strategic roles in consumer's decision making process, especially if there is a high involvement and risk of products or services with public facilities (Kotler, 2012).

Brennan's research (2004) concludes that there is possibility of applying the concept of consumer value in economic theory into politics. According to Woodruff (1997), consumer's perceived value should be conceptualized in three stages, such as: offering the characteristics, the consequences of offering benefits and consumer goals. In this tripartite concept, consumer value is conceptualized as a tool-goal hierarchy (Gutman, 1982). At the pre-purchase stage, consumers are interested in identifying and assessing bids as a group of characteristics. Then, after buying and utilizing the products, consumers will know the quality of the product. That means that consumers perceive the value, both in product utilization and ownership. At the final stage, consumers understand and relate to the achievement of their personal goals. Zeithaml (1988) defines perceived value as a consumer decision regarding the overall superiority and primacy of a product, dividing the components of perceived value into five parts, which include: brand name, reputation, intrinsic attributes objective price and perceived monetary price. This study will build a relationship between perceived value (Zeithaml, 1988) and other variables as studied in this paper.

Downs (1957) describes that one who selects rationally is capable of: 1) making decision when he/she deals with a set of choices, 2) ranking the available choices so that he/she can compare one choice to the others, 3) having a high level of assessment in choosing product, 4) selecting the best product according to his/her consideration, 5) taking similar decision every time faced with similar options. The decision-making process is depicted from three different stages, despite interrelated: starting from input, process and output (Schiffman \& Kanuk, 2014).

\subsection{Hypotheses}

The relationship between political products and voting decision was examined by Guzman and Sierra (2009). Their research demonstrates that 
the candidate's image has a positive influence on voting decision. There are practical opportunities to conduct political campaigns in the future. Research on the relationship between political promotion and voting decisions was examined by Baron et al. (2012). Ellis (2009) confirmed the relationship between political prices and voting decision. The premise of this study is charging prices to voters. Prices are often associated with economic costs, but there are still some prices or other costs that must be considered. The relationship between the place of politics and voting decision has been conducted by Dobrzynska et al. (2003). This study examines the direct influence of the media on voting decision. In the Election of DKI Jakarta Governor in 2012, there were three types of political marketing strategies that influence voting decision (Ediraras et al., 2013), which are: push marketing, pass marketing; and pull marketing. Based on the research conducted on marketing strategy, the researchers assume that Jokowi-Ahok applied those three strategies to win the election. Research conducted by Alwie (2011) stated that political products, political prices, political promotion, and political distribution influence the voting decision.

\section{H1: Political marketing mix has a positive effect on voting decision.}

The relationship between political products and perceived value has been investigated by Alkhawaldeh et al. (2016). In this context, trust in politics must be accurately proven and commitment plays an important aspect in voter's decision making. There were two examined variables, which are: trust and voter's commitment as independent variables to loyalty for political party. The results of Alkhawaldeh et al. (2016) study indicated that the two hypotheses tested were proven, concluding that the higher the confidence in political parties, the greater the influence on loyalty to political parties, and the commitment of voters was very closely related to their loyalty to political parties as well. In other words, a strong emotional relationship ultimately influences the decision made by voters.

The relationship between political promotion and perceived value has been reviewed by Fletcher and Slutsky (2014), pointing out that the campaign is aimed to change the perceptions of voters, one of which was about the position of the candidates in the issue spread among society. A positive campaign seeks to change the candidate's perception of his or her image or characteristics, while the negative campaign seeks to disfigure the image of the political opponents. Thus, each candidate chooses a mixes campaign in order to maximize the number of votes.

The relationship between political prices and perceived value has been reviewed by Zeithaml (1988) who divides propositions into two parts, of: propositions developed based on qualitative data from exploratory studies and other conceptual frameworks from the literature, and proposition for empirical evidence that supports and rejects the reviewed proposition. The relationship between the place of politics and the perception of value was reviewed by Hellweg (2011), focusing on how politicians are allowed to engage social media effectively and utilize this new media outlet as an important campaign tool. The utilization of social media by a politician significantly influences and enriches a voter's knowledge of public figure. The study has summarized the results of Hellweg (2011) research by stating that there is a definitive relationship between the application of social media by a politician and perceived value (the opinion of society). According to Brennan and Henneberg (2008), consumer's perceived value is closely related to the marketing approach and nature of organizations (consumer-oriented).

\section{H2: Political marketing mix has a positive effect on perceived value.}

The results of the research conducted by Alsamydai and Al Khasawneh (2013) found that all answers given by the research sample to various questions in this study (24 questions) are positive towards the means of all these questions. This conclusion is consistent with the assertion of Alsamydai (2000) regarding the specific criteria for the success of political candidates. Analysis of data on the third question related to the conversation skill of candidates depicts the highest value; the average of the median of 4.56, with a standard deviation value of 0.734 . Meanwhile, the twelfth question (regarding voter's confidence in the promise of political candidates) ranks the second highest with an average 
value of 4.54 and a standard deviation of 0.806 . However, the analysis of data on the tenth question related to the popularity of candidates' party has the lowest influence with an average median of 3.44 and a standard deviation of 1.161. The research of Shephard and Johns (2008) relevantly informed the influence of political products on the decision to vote political candidates in the elections of the UK. The results of research were conducted by social psychologists regarding the strong evidence of the relationship between physical appearance and impression or image. The results of the study indicated that people tend to conclude the characteristics of a person based on non-verbal behavior; by not creating many assessments of appearance, especially on facial expressions. Besides, the impression generated in this way then forms a strong urge to think about the object as captured buy our visual sight, which is deemed relevant as applied by the politicians.

Shephard and Johns (2008) also cited the findings of Rosenberg et al. (1986) that a person's physical appearance can give a general impression of the person, whether he/she is capable of completing their duty. The relationship between perceived value and voting decision within the conventional marketing environment was also studied by Tsiotsou (2005). Upon referring the theory of Zeithaml (1988), he confirmed that the consumer's perceived value results in the decision made by consumers regarding the overall superiority of a product. Consumer perceptions of quality differ from objective quality. Perception of product quality serves as a general assessment characterized by a high level of abstraction and refers to a specific consumption setting. Meanwhile, objective quality refers to the superiority of the actual technique of a product, which can be verified and measured (Monroe \& Krishman, 1985). The relationship between perceived value and voting decisions has been investigated by Rosenberg et al. (1986) who studied about how the appearance and the speech of a political candidate influence the opportunity of the political candidate including style shapes of the image which influence voting decision. Political experts began to examine the questions about people's perceptions of political candidates. Several researchers have examined the structure of community perceptions of political candidates. The results of the study conducted by Rosenberg et al. (1986) depicted that the personal qualities of political candidates greatly influence the perception of political candidates. In addition, the candidate's certain commonly desirable characters (religious, charismatic, kindhearted, famous, people-oriented) have a significant influence on the voters' decision to vote for certain political candidates.

\section{H3: Perceived value has a positive effect on voting decision.}

Relationship among candidate marketing, branding and voter's choice; the goal of a candidate who has decided to work in politics is to be the people's representative. Referring to social factors or political factors of the candidate, a candidate is portrayed as an unknown product, for which he must place himself in the voter market. Candidates are demanded to develop a personality (brand image) to get approval from an organization (company image), enter the main share of elections (market test), conduct vigorous campaigns (advertising and distribution), and place the voter target (market share). Candidates that can be marketed are selected by brand name, ability to attract voters, skills in engaging mass media, and ability to project their candidacy to the targeted voter segment. The position of a candidate takes certain issues, whether positive or negative in forming and projecting the brand's image and personality to the voters. Political candidates not only have to develop a marketing strategy in order to gain voters' supports but also to sustain their parties, contributors and voters (Nwanganga et al., 2017).

According to Scammell (2007), the general value of branding is both conceptual and practical to provide a conceptual framework for distinguishing and understanding the relationship between the perceptions of party's functional and leaders (conditions), such as economic management, policy commitment and competence to convey certain targets, and emotional attractiveness (such as 'one of us', authenticity, approachability, and attraction to both eyes and ears). Simultaneously, such branding value brings emotion and intellectual, rational and irrational (sometimes irrationally disturbing), big and small details, all of which are incorporated into the brand image. 


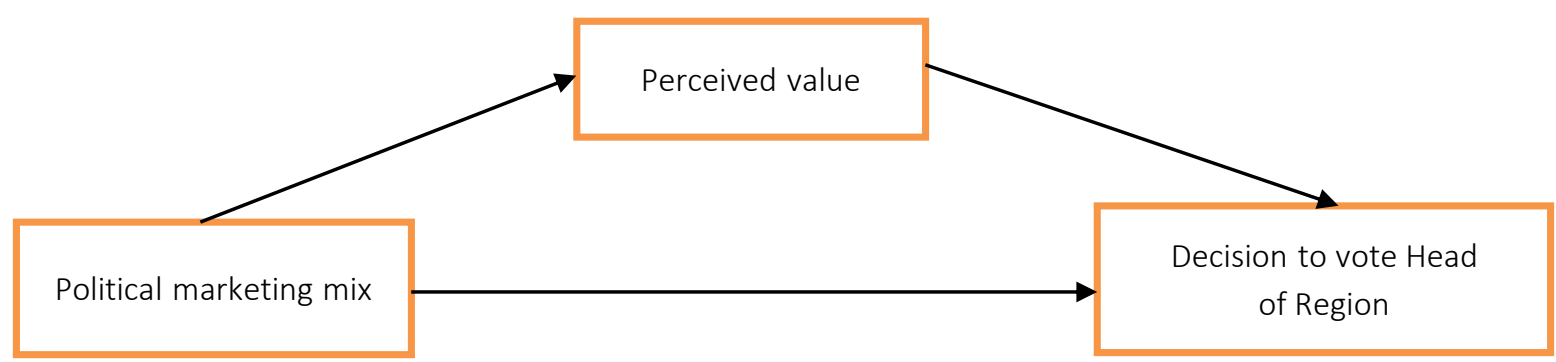

Figure 1. Conceptual framework

Brand concept becomes a powerful tool for understanding the political image. Political marketing challenges a typical version of the economy, which tends to not emphasize the importance of communication, popular culture and personality in politics to engage economics and aesthetics, rational choice and resonance (Scammell, 2015).

Lalancette and Raynauld (2017) studied online image management and its impact on the perceptions of leadership in the context of a digital campaign of political celebrity. The results of the study indicated that images can play an important role in politics; for voters specifically look for quality leaders, including: honesty, intelligence, friendliness, sincerity, and trust, when making decisions in voting. Image management techniques are helpful for voters to create the impression for politicians having certain characteristics. Political candidates can daily post pictures or videos to attract voters.

H4: Political marketing mix has a positive effect to nonvoting decisions through perceived value.

\section{RESEARCH METHOD}

\subsection{Population and sample}

This study employed a quantitative approach, with a population that refers to the whole group of people, events, or things of interest that the investigator wants to investigate (Sekaran, 2015). The population in this study involves residents of Banten Province who have the rights to vote and listed in the Permanent Voters List (DPT), amounting to $11,955,243$, consisting of $6,097,184$ men and $5,858,059$ women.
The Number of Permanent Voters List (DPT) for the Election of the Governor and Deputy Governor of Banten in 2017 is depicted as: (1) Cilegon City (8 sub-districts; 43 villages; 622 TPS (polling stations), with the number of voters was 281,369 people, consisting of 141,789 male voters and 139,580 female voters; (2) Serang City (6 sub-districts; 66 villages; 959 polling stations), with the number of voters was 455,291 people, consisting of 230,587 male voters and 224,704 female voters; (3) Tangerang City (13 sub-districts; 104 villages; 2,468 polling stations) with the number of voters was $1,127,914$ people, consisting of 567,445 male voters and 560,469 female voters; (4) South Tangerang City (7 sub-districts; 54 villages; 2,205 polling stations) with the number of voters was 881,382 , consisting of 437,448 male voters and 443,934 female voters; (5) Lebak Regency (28 sub-districts; 345 villages; 1,817 polling stations) with the of voters was 936,428 people, consisting of 478,102 male voters and 458,326 female voters; (6) Pandeglang Regency (35 sub-districts; 339 villages; 1,903 polling stations) with the number of voters was 920,320 people, consisting of 467,423 male voters and 452,897 female voters; (7) Serang Regency (29 sub-districts; 326 villages; 2,181 polling stations) with the number of voters was $1,109,495$ people, consisting of 561,328 male voters and 548,167 female voters; and (8) Tangerang Regency (29 sub-districts; 274 villages; 4,385 polling stations) with the total number of voters was $2,022,286$ people, consisting of $1,023,622$ male voters and 998,664 female voters.

Based on the Permanent Voters List (DPT) in the Election of Governor and Deputy Governor of Banten in 2017, the number of voters was 7,734,485 people, consisting of 4 districts and 4 cities covering 155 sub-districts, 1,551 villages and 16,540 
polling stations. The total number of male voters was 3,907,744, and the number of female voters was $3,826,741$ people (KPU Banten).

Based on the formula put forward by Isaac and Michael, the sample taken in this study was 664 people. In Banten Province, the respondents were spread across eight districts/cities, covering: Cilegon City, Serang City, Tangerang City, South Tangerang City, Lebak Regency, Pandeglang Regency, Serang Regency, and Tangerang Regency by applying proportional random sampling to polish the use of cluster sampling technique. In general, the employed technique in drawing research samples was a combination of two or three techniques. The number of samples taken from each regency/city in Banten Province consisted of: Cilegon City (24 people), Serang City (39 people), Tangerang City (97 people), South Tangerang City(76 people), Lebak Regency (80 people), Pandeglang Regency (79 people), Serang Regency (95 people), and Tangerang Regency (174 people).

This study applied a Likert scale (1-5) indicating: Strongly Disagree (Score 1), Disagree (Score 2), No Opinion/Neutral (Score 3), Agree (Score 4), and Strongly Agree (Score 5). In this study, data were collected through structured interviews with respondents, to obtain information about the issues under the study. In addition to interviews, this study also utilized questionnaires. This study employed SEM (Structural Equation Modeling) and data analysis was completed by using WarpPLS 6.0.

\subsection{Research instrument}

To measure the political marketing mix, this study involved the dimensions formulated by Niffenegger (1988), consisting of: political products, political promotion, political prices, and political places. For the voting decision, the researchers employed a measurement scale as developed by Solomon (1999) with four indicators, such as: problem recognition, information retrieval, alternative evaluations, election transparency. To obtain the perceived value, the researchers utilized the four indicators adopted from Zeithaml (1988), which included: competitive advantage, political attributes, figure quality, and brand name.

\section{RESULTS}

Based on the socio-demographic data of the respondents, the percentage of male respondents is 53.16 percent, and the percentage of female respondents is 46.84 percent. Based on age, the majority of respondents are between 32 and 46 years (39.31 percent). Based on the level of education, the last education of the majority of respondents is high school (43.07 percent). Based on the occupation, the majority of respondents choose other jobs (56.63 percent) and private employees (19.28 percent). 'Other jobs' indicates that the respondents consist of people with various occupations, such as temporary labor or outsourcing (contract), honorarium workers, freelancers, housewives, unskilled employed, applied to eight regencies/cites in Banten Province. Based on the amount of incomes, the majority of respondents receive income of less than 5 million (88.86 percent). In eight regencies/cities in Banten Province, the majority of respondents are from Tangerang Regency (26.05 percent).

\subsection{Evaluation of outer model for political marketing mix}

Table 1. The results of evaluation of outer model for political marketing mix

\begin{tabular}{l|l|c|c}
\hline \multicolumn{1}{c}{ Variable } & Indicator & $\begin{array}{c}\text { Loading } \\
\text { factor }\end{array}$ & Average \\
\hline \multirow{2}{*}{$\begin{array}{l}\text { Political } \\
\text { marketing mix }\end{array}$} & $\begin{array}{l}\text { Political product } \\
\text { promotion }\end{array}$ & 0.719 & 3.23 \\
& Political price & 0.788 & 3.03 \\
& Political place & 0.747 & 2.892 \\
\hline
\end{tabular}

Political marketing mix applied several indicators, such as: political product, political promotion, political price and political place. Of the four indicators, one that best reflects political mix marketing is political promotion; as seen from the loading factor of political promotion amounting to 0.788 . This result indicates that political promotion provides the biggest contribution to the political marketing mix. The average score that reflects the statement of voters for political promotion is quite high (3.03). However, the average score that describes the statement of voters for political products has the highest value. 


\subsection{Evaluation of outer model for perceived value}

Table 2. The results of evaluation of outer model for perceived value

\begin{tabular}{c|l|c:c}
\hline \multicolumn{1}{c}{ Variable } & \multicolumn{1}{|c|}{ Indicator } & $\begin{array}{c}\text { Loading } \\
\text { factor }\end{array}$ & Average \\
\hline \multirow{3}{*}{ Perceived value } & $\begin{array}{l}\text { Competitive } \\
\text { advantage }\end{array}$ & 0.680 & 3.37 \\
\cline { 2 - 4 } & $\begin{array}{l}\text { Political } \\
\text { attribute }\end{array}$ & 0.666 & 2.78 \\
& $\begin{array}{l}\text { Figure quality } \\
\text { Brand name }\end{array}$ & 0.841 & 3.50 \\
& Brand & 0.818 & 3.51 \\
\hline
\end{tabular}

Perceived value is a latent variable which is measured by using 4 reflective indicators, including: competitive advantage, political attributes, quality of figures and brand names. The most indicator that strengthened the perceived value is the quality of the figure as seen from the loading factor of figure quality amounting to 0.841 . This result means that the figure quality becomes an indicator with the largest contribution to the perceived value. Meanwhile, the average score that reflects voters' statement for figure quality is quite high (3.50). However, the average score that describes the voter's statement for the brand name has the highest result (3.51).

\subsection{Evaluation of outer model for voting decision}

Table 3. The results of evaluation of outer model for voting decision

\begin{tabular}{|c|c|c|c|}
\hline Variable & Indicator & $\begin{array}{l}\text { Loading } \\
\text { factor }\end{array}$ & Average \\
\hline \multirow{3}{*}{$\begin{array}{l}\text { Voting } \\
\text { decision }\end{array}$} & $\begin{array}{l}\text { Introduction to the } \\
\text { issue }\end{array}$ & 0.807 & 3.05 \\
\hline & $\begin{array}{l}\text { Information } \\
\text { collection }\end{array}$ & 0.809 & 3.20 \\
\hline & $\begin{array}{l}\text { Alternative } \\
\text { evaluation }\end{array}$ & 0.803 & 3.08 \\
\hline
\end{tabular}

Voting decision is a latent variable which is measured using 3 reflective indicators, such as: problem recognition, information collection and alternative evaluation. Meanwhile, voting decision is discarded as this indicator does not meet the criteria. The indicator presenting the highest voting decisions is information collection, as seen from the value of the information search loading factor of 0.809 . This result apparently depicts that informa- tion collection dominantly contributes to voting decision. The average score that reflects the voter's statement for the information collection is quite high (3.20).

\subsection{Hypotheses testing}

Table 4. Test results of variable mediation by using Sobel method for the relationship between political mix marketing and voting decision through perceived value

\begin{tabular}{c:c:c:c:c:c}
\hline No & Procedure & Coefficient & $\boldsymbol{t}$ value & $\boldsymbol{P}$ value & Note \\
\hline 1 & PN $\rightarrow$ KM & 0.0813 & 3.6929 & 0.0001 & Significant \\
\hline
\end{tabular}

Note: political marketing mix, PN: perceived value, KM: voting decision.

The results of the Sobel test for the relationship between political marketing mixes and voting decision through perceived value indicates significant results. Perceived value is proven as a mediating variable for the influence of political marketing mix on voting decision.

The picture above demonstrates that all hypotheses (H1-H4) are accepted. The path coefficient of political marketing mix on the decision to vote in the Election of the Governor and Deputy Governor of Banten, amounts to 0.40. The path coefficient is significant at alpha $5 \%$. This finding supports the results of research conducted by Alwie (2011), Ediraras et al. (2013), Arofah and Nugrahajati (2014) clarifying that political marketing mix politic has a significant effect on the decision to vote, in which higher and better political marketing mix will lead to better voting decision. The path coefficient of political marketing mix on the perceived value of the candidates in the election of the Governor and Deputy Governor of Banten amounts to 0.56 . The path coefficient is significant at alpha $5 \%$, which is relevant with the results of research conducted by Alkhawaldeh et al. (2016), Fletcher and Slutsky (2014), Zeithaml (1988) claiming that political marketing mix has a significant effect on perceived value. The finding further confirms that higher and better political marketing mix creates better perceived value. The path coefficient of perceived value for voting decision in the Election of the Governor and Deputy Governor of Banten amounts to 0.15 . The path coefficient is significant at alpha $5 \%$. This 
$R^{2}=0.31$

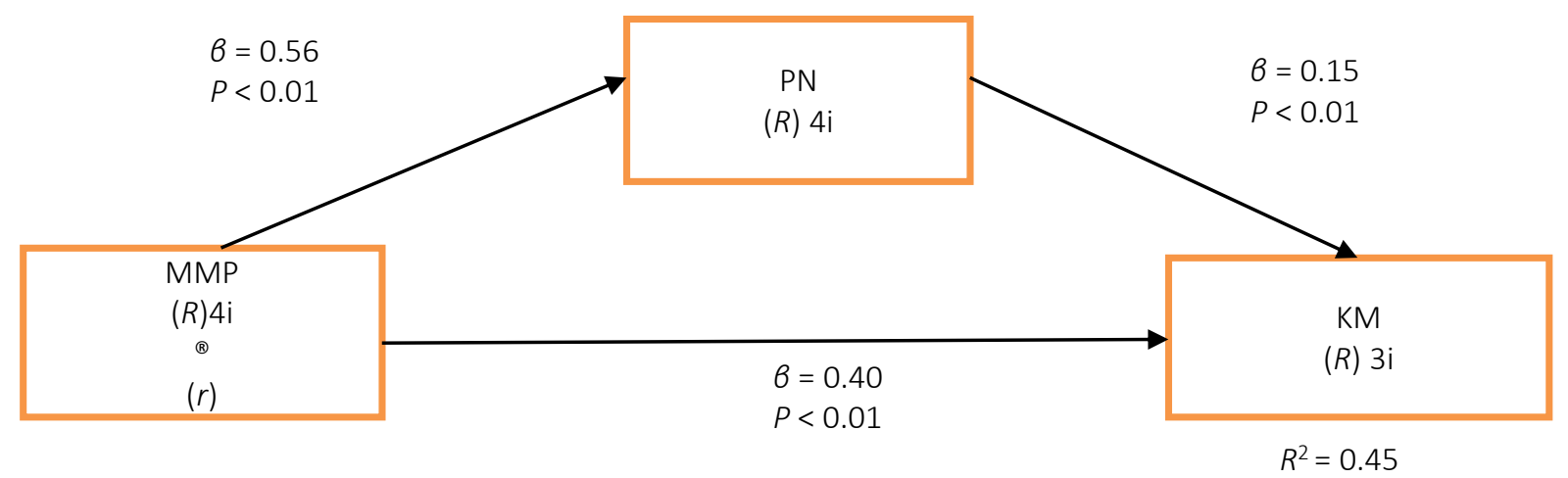

Note: MMP: political marketing mix, PN: perceived value, KM: voting decision, ${ }^{*}$ : significant at alpha 5\%.

Figure 2. Structural equation model coefficient. The Role of Perceived Value as a Mediator for Political Marketing Mix on Decision to Vote Head of Regions

finding supports the results of a study conducted by Rosenberg et al. (1986), Shephand and Johns (2008), Tsiotsou (2005) insisting that perceived value has a significant effect on the decision to vote, where higher and better the perceived value, leads to better voting decision. The path coefficient of political marketing mix on the voting decision through perceived value in the Election of the Governor and Deputy Governor of Banten amounts to 0.0813 . The path coefficient is significant at alpha 5\%. Higher and better political marketing mix and perceived value leads to better voting decision. This result supports the research conducted by Zeithaml (1988) and Shephand and Johns (2008) that perceived value was as a mediating variable for influencing political marketing mix on voting decision.

\section{DISCUSSION}

The theory establishes the relationship between political marketing mix independent variables and other variables, which was from Niffenegger's theory (1988) describing political marketing mix along with its indicators such as political products, including: (1) Party platform, (2) Past record (notes about the past), and (3) Personal characteristics; as well as (4) Political promotion, which are: (1) Advertising, (2) Publication (3) Debate event. Political prices (1) Economic costs, (2) Psychological costs, (3) National image effects; and Political places, which include: (1) Personal marketing programs, (2) Voluntary programs. Indicators forming political marketing mix variables are presented by political promotion to improve the political marketing mix through campaign advertisements, publications, and debate advertisements.

The decision to vote becomes the dependent variable. The decision theory for voting (Solomon, 1999) has the following indicators of: problem recognition, information search, alternative evaluation and decision making. Based on the value of the loading factor as forming variables, the decision to choose is information seeking. Increasing information retrieval is necessary to pursue to improve voting decisions for properly elected candidates. This attempt indicates that the indicators forming the decision variable deals with the search for information on candidates; thus, voters will have the right choice.

Then, the intervening variable (mediation) employs the theory of perceived value (Zeithaml, 1988) and indicators of perceived value, which include: competitive advantage, political attributes, figure quality and the brand name. The quality of figures indicates the loading factors forming perceptual variables to improve the conceptual perception of good leadership figures from the candidates. The concept of value perception theory plays as an important element in the development 
of methods and strategies for winning the political competition (Rosenberg et al., 1986; Tsiotsou, 2005; Shephard \& Johns, 2008; Alsamydai \& Al Khasawneh, 2013).

Voters in Banten Province explained their political views through their decision to vote for the political candidates. They tend to review the track records of the selected figures. Based on the candidates' track records, the voters can conclude whether the candidate is worth to vote. If they assume that a candidate has a good achievement, they will vote for him/ her. In quest for loyalty, voters tend to not easily swift their choices even though the candidate had a bad record.

However, personal characteristics of a candidate greatly determine the voting decision, which generally cover: visionary; protective; honesty and integrity; authoritative; smart and innovative; mature; experienced; has good physical appearance; popular among the society, and attractive-look. The voters in Banten Province assume that their leader should meet those criteria along with several political products, such as: party platform; track records; personal characteristics as the driving factor for voting decision.

The candidates are very concerned about promotional strategies to introduce their figures to the public. Promotion was carried out massively both by political candidates and the candidates, before the campaign period until the silent period (within three days before the election day). Each political party is acutely aware that massive political advertising will have an electoral impact on him. Through advertisements, voters in Banten Province comprehend the profile of the candidates to vote.
During the campaign period, political candidates in Banten Province conducted promotional advertisements through various media channels, such as: television, radio, newspapers, billboards, banners, stickers, websites and social media (Facebook, Twitter, and Instagram) and other promotional attributes. Through the media, political candidates communicate messages to the public, presenting and promoting the profile of political candidates, vision-missions and work programs and offer development ideas in favor of the people.

During the campaign period, the KPU held a debate event on television in order to facilitate political candidates to debate on vision-mission and work programs. The debate is guided by moderators and independent panelists. Through this event, people in Banten Province comprehend the leadership qualities and competencies of each political candidate. The effect of promotion, especially television through advertising, is considered quite effective in influencing the positive image of political candidates along with other means of political promotion, such as: media publications; debate event, the decision driving factor of voting.

Unfortunately, the political candidates in Banten Province do not have the image of a national figure, as their names are only recognized at the provincial/local level. Even though they are famous at the national level, they did not have outstanding achievements and positive image. Voters considered them as local figures that did not have any achievement on a national scale and only worked hard to build their image to improve their branding.

\section{CONCLUSION}

According to established theories and based on proven previous research, political products, political promotion, political prices (cost of politic/expenses for politic) and political places have a directly or indirectly significant influence on voting decision. Voters have a positive perception of political candidates because the political marketing mix variable offered by political candidates fulfils the expectations of prospective voters. A theory adapted from political marketing mix provides a managerial solution to manage the supporting teams of the candidates. Political candidates can apply political marketing mix in the election (for governor/deputy governor), including the election of president, governors/regents/ mayors, DPR-RI (House of Representatives) /DPRD (Regional House of Representatives), and DPD (Regional Representatives Council). 
Perceived value is in line with the established theories in business marketing, which is applicable to political marketing. This study signifies that the perceived value, competitive advantage, political attributes, quality of figures, and brand name, provide a directly or indirectly significant influence on voting decision. Specifically in this study, perceived value serves as a research gap and a novelty, since the concept of value perception theory has been a decisive variable in political marketing strategy. To add, perceived value is also an important variable to be tested in future studies, offering a must-accomplish-strategy that should be pursued by political candidates in order to win the election. The concept of perceived value is significantly relevant to be applied or practiced by political candidates in the election, such as in Pilgub (election of governor/vice governor) or other elections (Presidential Election, Election of Regional Heads and Legislative).The concept of perceived value is a combination of marketing management (economic and business/consumer behavior) and political marketing. Linearly, the concept of perceived value in business marketing can be tested in political marketing, indicating appropriate result of theoretical relevance. The difference only lies in the object of research related to market of business and market of political markets.

Voting decision includes an introduction to problem, information collection, and alternative evaluation indicating that the concept of voting decision theory is a dependent variable. Thus, the concept of decision making in business marketing (consumer behavior) is applicable to be applied as a theoretical concept of political marketing.

This study suggests the future researchers to back up the data in other devices in order to avoid loss of data.

\section{REFERENCES}

1. Alkhawaldeh, A. M., Salniza, Bt.Md. S., \& Fairol, bin H. (2016). An Empirical Study in Voting Behaviour and Political Brand.International Business Management, 10(18), 4365-4372. Retrieved from http://docsdrive. com/pdfs/medwelljournals/ ibm/2016/4365-4372.pdf

2. Alsamydai, M., \& Khasawneh, M.(2013). Basic Criteria for the Success of the Electoral Candidates and their Influence on Voters' Selection Decision. Advances in Management \& Applied Economics, 3(3), 105-127. Retrieved from https://www.zuj. edu.jo/wp-content/staff-research/ economic/dr.mohmood-Jasim/1. pdf

3. Alsamydai, M. J. (2000). Political marketing, principle and strategies. Dar Zehran for publishing and distribution, 48, 171. Retrieved from https://pdfs.semanticscholar. org

4. Alwie, A.F. (2011). Political Marketing and the Decision to Choose Regional Head Election
Participants in Urban and Suburban Groups (Study of Political Participants in Pekan Baru City) (Unpublished Dissertation). PDIM FEB Universitas Brawijaya, Malang.

5. Arofah, K., \& Nugrahajati, S. D. (2014). Political Marketing Conducted by Legislatives in Indonesia: Study of Public Transportation as Transit Media in Medan on President Election 2014. Procedia - Social and Behavioral Sciences, 155, 153-158. https://doi. org/10.1016/j.sbspro.2014.10.272

6. Assael, H. (1995). Consumer behavior and marketing action. Cincinnati, Ohio, South-Western College.

7. Barton, J., Castillo, M., \& Petrie, R. (2012, June 18). What Persuades Voters? A Field Experiment on Political Campaigning. GMU Working Paper in Economics No. 12-31. https://doi.org/10.2139/ ssrn. 2087135

8. Bennett, R. (1997). Export Marketing and the Internet: Experiences of Web Site Use and Perceptions of Export Barriers among UK Business. International Marketing Review, 14(5), 324-344. https://doi. org/10.1108/02651339710184307

9. Brennan, R. (2004). Does Political Marketing Need the Concept of Customer Value (Working Paper). Middlesex University Business School. Retrieved from https://www. emerald.com/insight/content/ doi/10.1108/02634500810902820/ full $/ \mathrm{html}$ ?fullSc $=1 \& \mathrm{mbSc}=1$

10. Chang, T.-Z., \& Wildt, A. R. (1994). Price, product information, and purchase intention: An empirical study. Journal of the Academy of Marketing Science, 22(1), 16-17. Retrieved from https://link.springer.com/article/10.1177/0092070394221002

11. Dobrzynska, A., Blais, A., \&Nadeau, R.(2003). Do the Media Have a Direct Impact on the Vote? International Journal of Public Opinion Research, 15(1), 27-43. https://doi.org/10.1093/ ijpor/15.1.27 
12. Downs, A. (1957). An Economic Theory of Political Action in a Democracy. Journal of Political Economy, 65(2), 135-150. Retrieved from https://www.jstor. org/stable/1827369? seq=1\#page_ scan_tab_contents

13. Eavani, F., \& Nazari, K. (2012). Marketing mix: a critical review of the concept. Elixir Marketing, 49, 9914-9920.Retrieved from https:// www.semanticscholar.org/paper/ Marketing-mix $\% 3 \mathrm{~A}$-a-criticalreview-of-the-concept-Eavani-Naz ari/819debe30429b9889bd14aeacd cd2ec1e7e97e87

14. Ediraras, D. T., Rahayu, D. A., Natalina, A., \& Widya, W.(2013). Political Marketing Strategy of Jakarta Governor Election in the 2012s.Procedia-Social and Behavioral Sciences, 81, 584-588. https://doi.org/10.1016/j.sbspro.2013.06.480

15. Ellis, A. R. (2009). The Cost of the Vote: Poll Taxes, Voter Identification Laws, and the Price of Democracy. Denver University Law Review, 86(3). Retrieved from https://papers.ssrn.com/sol3/papers.cfm?abstract_id $=1554667$

16. Felton, A. P. (1959). Making the Marketing Concept Work. Harvard Business Review, 37, 55-65.Retrieved from http://www.scirp.org/ (S(351jmbntvnsjtlaadkposzje))/ reference/ReferencesPapers. aspx?ReferenceID=1518124

17. Firmanzah (2007). Political Marketing: Between Understanding and Reality. Obor Indonesia Foundation, Jakarta.

18. Firmanzah (2010). Competition, Legitimacy, and Political Marketing: Learning Politics in Elections 2009. Obor Indonesia Foundation, Jakarta.

19. Fletcher, D., \& Slutsky, S. (2014). A Little Bit Nasty, Some of the Time: Mixed Strategy Equilibria in Political Campaigns with Continuous Negativity. Retrieved from http://citeseerx.ist.psu.edu/viewdoc/ summary?doi=10.1.1.685.2710

20. Guzman, F., \& Sierra, V. (2009). A political candidate's brand image scale: Are political candidates brands? Journal of Brand Management, 17(3), 207 217. https://doi.org/10.1057/ bm.2009.19

21. Hellweg, A. (2011). Social Media Sites of Politicians Influence Their Perception by Constituents. The Elon Journal of Undergraduate Research in Communications, 2(1), 22-36. Retrieved from https://www.elon.edu/u/ academics/communications/ journal/wp-content/uploads/ sites/153/2017/06/03Hellweg.pdf

22. Henneberg, S. C. (2008). An Epistemological Perspective on Research in Political Marketing. Journal of Political Marketing, 7(2), 151-182. https://doi. org/10.1080/15377850802053158

23. Kotler, P. (2012). Marketing Management. Jilid I and II, PT. Indeks, Jakarta.

24. Lalancette, M., \& Raynauld, V. (2017). The Power of Political Image: Justin Trudeau, Instagram, and Celebrity Politics. American Behavioral Scientist, 63(7), 888-924. https://doi.org /10.1177\%2F0002764217744838

25. Mccarthy, E. J. (1964).Basic Marketing. IL: Richard D. Irwin.

26. Monroe, K. B., \& Krishnan, R. (1985). The Effect of Price on Subjective Product Evaluations. In J. Jacoby \& J. Olson (Eds.), The Perception of Merchandise and Store Quality (pp. 209-232). Lexington Books.

27. Newman, B.I., \& Perloff, R.M. (2004). Political Marketing: Theory, Research, and Applications. Handbook of Political Communication Research.

28. Niffenegger, P. B. (1988). Strategies for Success from the Political Markerters. Journal of Services Marketing, 2(3), 15-21. https://doi. org/10.1108/eb024729

29. Nursal, A.(2004). Political Marketing: Strategy to Win Elections: A New Approach to the Election Campaign for DPR, DPD, President. Gramedia Pustaka Utama, Jakarta.

30. Nwanganga, A. P., Peter, N. C., \& Mirian, U. (2017). Political
Branding/Brand Personality and Voters' Choice of Candidate: An Empirical Inquiry into 2015 Presidential Election in Nigeria. Journal of Marketing and Consumer Research, 37. Retrieved from https://iiste.org/Journals/index.php/JMCR/article/view/38058

31. O'Cass, A. (2001). Political marketing - An investigation of the political marketing concept and political market orientation in Australian politics. European Journal of Marketing, 35(9/10), 1003-1025. https://doi. org/10.1108/03090560110401938

32. Palmer, A. (2004). Introduction to Marketing - Theory and Practice. UK: Oxford University Press.

33. Parasuraman, A. (1997). Reflections on Gaining Competitive Advantage through Customer Value. Journal of the Academy of Marketing Science, 25, 154-161. https://doi.org/10.1007/ BF02894351

34. Rosenberg, S. W., Bohan, L., Mc Cafferty, P., \& Harris, K. (1986). The Image and the Vote: The Effect of Candidate Presentation on Voter Preference. American Journal of Political Science, 30(1), 108-127. Retrieved from http:// links.jstor.org/sici?sici=0092$5853 \% 28198602 \% 2930 \% 3 \mathrm{~A} 1 \% 3$ C108\%3ATIATVT\%3E2.0.CO\% 3B2-3

35. Scammell, M. (2007). Political Brands and Consumer Citizens: The Rebranding of Tony Blair. The ANNALS of the American Academy of Political and Social Science, 611(1), 176-192. Retrieved from https://www.jstor. org/stable/25097916

36. Scammell, M. (2015). Politics and Image: the conceptual value of branding. Journal of Political Marketing. https://doi. org/10.13140/2.1.4447.6165

37. Schiffman, L. G., \& Kanuk, L. L. (2007). Consumer Behavior (9th ed.). Prentice Hall, Upper Saddle River.

38. Shephard, M., \& Johns, R. (2008). Candidate Image and Electoral Preference in Britain. British Politics, 3(3), 324-349. https://doi. org/10.1057/bp.2008.8 
39. Solomon, M. R. (2004).

Consumer Behavior, Buying,

Having and Being (6th ed.).

Pearson Prentice Hall. Education International.

40. Tsiotsou, R. (2005). The role of perceived product quality and overall satisfaction on purchase intentions. International Journal of Consumer Studies, 30, 207-217. https://doi.org/10.1111/j.14706431.2005.00477.x
41. Widagdo, S., Armanu, N., \& Rofiyati (2014). Effect of Political Marketing Mix on Constituents Behavior in Selecting Candidates dan Political Parties: Theoretical Studies in Legislative Election. International Journal of Business and Management Invention, 3(10), 47-54. Retrieved from https://www.ijbmi.org/papers/Vol(3)10/Version-2/ F03102047054.pdf
42. Woodruff, R. B. (1997). Customer Value: The Next Source for Competitive Advantage. Journal of the Academy of Marketing Science, 25(2), 139-153. http://dx.doi. org/10.1177/0092070397253006

43. Zeithaml, V.A. (1988). Consumer Perceptions of Price, Quality, and Value: A Means-End Model and Synthesis of Evidence. Journal of Marketing, 52(3), 2-22. https://doi. org/10.1177/002224298805200302 